
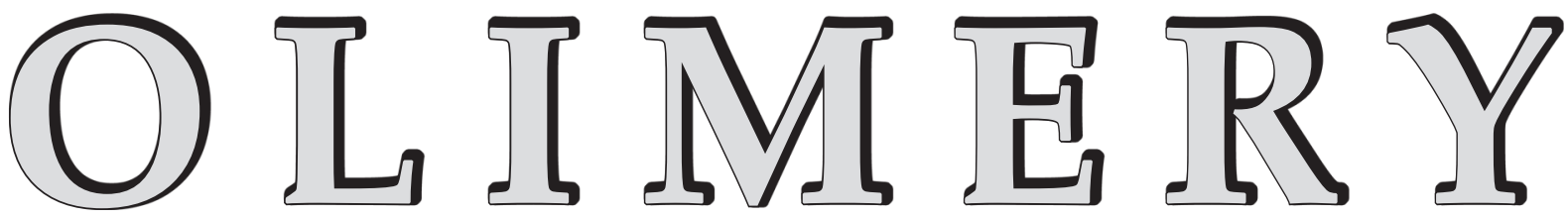

\title{
Polymers in gearbox production
}

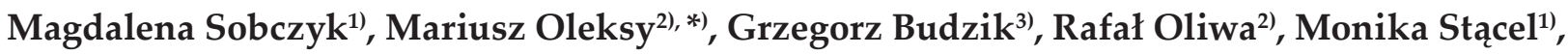 \\ Henryk Majcherczyk ${ }^{1)}$
}

DOI: dx.doi.org/10.14314/polimery.2020.11.1

\begin{abstract}
Technological progress spurs the creation of new machine designs, the development of new highly advanced technologies, as well as the introduction of new materials, including polymeric ones, that meet the economic and ecological criteria. An analysis of the literature reveals that there are few works outlining the rules for the design of machine components using polymeric materials, including composites and nanocomposites. This article is a review of the literature on the use of polymer matrix thermoplastic composites (PA6 - polyamide 6, PA66 - polyamide 66 and POM - polyoxymethylene) in toothed transmission systems. The presented examples demonstrate the production of hybrid polymer nanocomposites with addition of inorganic fillers and their application in the manufacture of machine components, including gears.
\end{abstract}

Keywords: hybrid polymer composites, gears, gearboxes, machine components, polyamide 6, polyamide 66, polyoxymethylene.

\section{Materiały polimerowe stosowane do otrzymy wania przekładni zębatych}

Streszczenie: Rozwój techniki determinuje tworzenie nowych konstrukcji maszyn, opracowywanie nowych, wysoko zaawansowanych technologii, jak również wprowadzanie nowych materiałów, w tym polimerowych, spełniających kryteria ekonomiczne i ekologiczne. Dane literaturowe wskazują, że niewiele publikacji opisuje zasady postępowania podczas projektowania konstrukcji elementów maszyn z wykorzystaniem materiałów polimerowych, jak również ich kompozytów i nanokompozytów. Artykuł stanowi przegląd literatury dotyczącej zastosowania kompozytów na osnowie polimerów termoplastycznych (PA6 - poliamid 6, PA66 - poliamid 66 i POM - polioksymetylen) w zębatych układach przeniesienia napędu. Opisano przykłady otrzymywania hybrydowych nanokompozytów polimerowych wzmacnianych napełniaczami nieorganicznymi i ich wykorzystania w wytwarzaniu elementów maszyn, w tym kół zębatych.

Słowa kluczowe: hybrydowe kompozyty polimerowe, koła zębate, poliamid 6, poliamid 66, polioksymetylen, przekładnie zębate, elementy maszyn.

Over the years, the machine building industry has begun to appreciate the economic and technical aspects of using polymer gearboxes. This may be due to the fact that their performance characteristics (lower weight, lower

\footnotetext{
1) SPLAST Sp. z o.o., Lotników 13, 38-400 Krosno, Poland.

2) Rzeszow University of Technology, Department of Polymer Composites, al. Powstańców Warszawy 6, 35-959 Rzeszów, Poland.

3) Rzeszow University of Technology, Department of Mechanical Engineering, al. Powstańców Warszawy 8, 35-959 Rzeszów, Poland.

*) Author for correspondence: molek@prz.edu.pl
} 
costs, lack of lubrication and maintenance, etc.) are different than those of their metal equivalents. Polymer gearboxes have a significant advantage over their metal counterparts, which argues for their popularization. This is owing to the fact that there are incomparably more types of polymeric materials than all other metallic engineering materials. By using a combination of appropriately selected fillers, nanofillers or other modifiers, the properties of almost every basic polymer can be extremely changed. However, it should be noted that the properties of polymeric materials are clearly different than the properties of metallic ones. By making a direct comparison, it can be concluded that metals have a higher: density, maximum service temperature, stiffness/strength, and thermal and electrical conductivity. Plastics, in turn, have much better mechanical damping, thermal expansion, elongation at break and ductility. A significant advantage of polymeric gearboxes is the ability to work without external lubrication, fast and relatively cheap production, and the ability to dampen moderate shocks and impacts [1-4].

Therefore, metal gear equivalents made of polymeric materials do not undergo chemical corrosion, which translates into reduced maintenance costs. Other important benefits are lower weight as well as lower noise emissions during operation, less friction and lower production costs. These features are very important in the case of large production volumes of complex machine components produced in the injection molding process [5]. Polymer gearboxes used in the automotive industry in place of their metal equivalents allow a reduction of the weight of gearbox components by up to $70 \%$ while reducing inertia by $80 \%$, and thus reduce energy (fuel) consumption by up to $9 \%$ [6].

The differences in the operation of both types of gears are due to the fact that the elasticity modulus of polymers is about one hundred times lower than for most metals and thirty times lower than that of aluminum. This increases the contact time between the gear teeth during operation. The low modulus that polymer gearboxes have should improve operation through better distribution of contact force and noise reduction during work [7].

However, the popularization of polymer gears is limited due to a small number of standards and design rules for polymer gearboxes [8]. The second reason behind this is the high sensitivity of polymer gearboxes to temperature. It has a direct effect on nonlinear changes in viscoelastic and mechanical properties of polymers $[9,10]$. The result of the temperature on the tooth surface is mainly influenced by the ambient temperature and a short-term increase in temperature when the gears mesh.

The difficulty in determining the temperature at the time of contact is due to the fact that it falls sharply when the gear stops. The temperature value is also influenced by the transmitted torque, specific weight, gear dimensions, sliding speeds and poor thermal conductivity of polymers $[8,11]$.
The main problem of polymer gearboxes is the heat generated by friction, as well as contact and bending hysteresis at the top and base of the tooth, respectively. They cause uneven temperature distribution with local concentrations due to low thermal conductivity of polymers. This effect is described in Hertz's contact theory. The theory stipulates that two bodies with curved surfaces come into contact under force or torque, and the surface contact between them changes. As a result, additional stresses appear, which affect the strength of the gear system components $[3,9,10]$.

The exerted stresses cause failures, the most common being surface wear and tear or pitting, as well as deformation and cracking of teeth at the base. Small material losses are caused by repeated surface stresses that exceed the material strength limit. Temperature spikes are the main cause of tooth base cracks. For this reasons, the service life of polymer gears is often limited by low torques. One should also note the maximum temperature on the tooth surface on working time of gearboxes, which during operation is a test limiter [5, 7]. An additional obstacle is the large range of measurement error after stopping the gear due to a sudden temperature drop [3]. Gearboxes used for power and motion transmission can be damaged in many ways. The motion that is performed during their operation is a rolling and sliding motion, which causes a decrease in performance and lower power transmission [6]. Studies have shown that the gearbox material, torque, and speed have a significant impact on the performance of these components. Thermoplastic materials such as polyamides 6 (PA6), polyamides 66 (PA66) and polyacetals (POM) are most commonly used in the production of gears. Polycarbonates (PC), polyurethanes (PUR) or polyesters are used less frequently to obtain gearbox components [12].

Replacing metal gearbox components with polymer ones requires a complete change of the product design concept, including a simplified shape. The design process of polymer machine components must therefore take into account the functional properties of the polymers selected for this purpose.

The basic mechanical properties of most polymers depend on ambient temperature. On the other hand, mechanical properties of metals hardly change until the recrystallization temperature exceeds $300^{\circ} \mathrm{C}[13,14]$.

In recent years, a dynamic development of polymeric materials that are used in the manufacture of machine elements, including toothed drive system components, has been observed. The components are manufactured on a large scale from engineering composite materials based on a PA, POM, PC or acrylonitrile-butadienestyrene (ABS) matrix using injection molding $[15,16]$ or material removal (cutting, electrical discharge machining (EDM) on computerized numeral control (CNC) machines (gear hobbing, milling with an end mill or formed cutter, CNC milling by cutting out the tooth shape) [17-19]. Thanks to the injection molding technology, it is possi- 
ble to obtain up to several hundred pieces in one injection cycle, depending on the number of mold cavities (the higher the number, the more profitable the production). Unfortunately, it is highly unprofitable to produce an injection mold for a small number of gear prototypes. In the case of material removal processes, the cost per wheel is also considerable, while the raw materials used include polymers that can be machined [polyoxymethylene - POM, polyamide - PA, polytetrafluoroethylene - PTFE, polycarbonate - PC, poly(ethylene terephthalate) - PET and poly(methyl methacrylate) - PMMA]. At the same time, progress can also be observed in the improvement of new polymeric materials for machine components used in the quickly developing rapid prototyping techniques. This synergy of operation makes it possible to produce very precise prototypes of large and small series.

To sum up this part of the paper, it can be stated that the literature provides very little information on the rules of designing machine components using modern polymers and their composites or nanocomposites, and, consequently, the criteria for the selection of techniques for molding such products from polymers. For this reason, the further part of this study has been devoted to the use of such polymers in the manufacture of gearbox components with injecting molding and 3D technics. The principles for the design of machine components using polymeric materials are presented, and the criteria of polymeric material selection and processing technology are discussed.

\section{POLYAMIDE AND POLYAMIDE COMPOSITE GEARBOXES}

Polyamides have very good structural properties such as mechanical strength and tensile strength. They also exhibit high stiffness, hardness, as well as high abrasion resistance and a low friction coefficient. One of the biggest advantages of polyamides (PA) is their shape stability at high temperatures. They show good resistance to chemicals and various types of solvents, for example petrol, oils, they are also good insulators and offer relatively high water absorption. PA can be processed mainly by injection and extrusion [16].

There are several types of polyamides used in the production of machine components, for example PA66, which has much higher mechanical strength and chemical resistance compared to the basic PA6. The increased strength of this polymer results in a lower ability to dampen vibrations and a lower impact strength. Polyamide 66 reinforced additionally with glass fiber, for example at $30 \%$ of its volume (PA66 GF30), has a higher mechanical strength, better dimensional stability, better stiffness as well as higher creep resistance at higher operating temperatures than PA6 [20-22].

Another very popular polyamide is PA6-G (cast polyamide), which has excellent machinability and very good mechanical properties, and is much harder than PA6. It is characterized by low weight, corrosion resistance, high vibration damping capacity, and abrasion resistance. Due to the low coefficient of friction, parts made of PA6-G are effective without lubrication. The plastic is used in the engineering, food, mining and metallurgical industries. It can be used to obtain, for example, rollers for transport devices, spacer sleeves, chain guides, various types of wheels, and many other products [13].

In conclusion, PA6 and PA66 have the greatest industrial significance in the production of machine components. They are very similar except that the monomer used to produce PA6 is cheaper and more easily accessible than the raw materials for PA66 [23, 24].

Despite the wide use of polyamide gearboxes, they still have such disadvantages as lower load capacity and shorter service life. These properties limit the use of polyamide gearboxes in high speed systems working under high loads or in high ambient temperatures. The main causes of mechanical damage, i.e. breaking of parts or whole teeth, are fatigue and deformation of the material due to an increase in surface temperature. For this reason, the accumulating heat must be strictly controlled and effectively removed. It results from the thermal conductivity of polymeric materials being lower than in the case of metals [25]. Terashima's team [25] performed tests to determine the temperature on the surface of polymer gears operating at room temperature. Research shows a temperature distribution, which clearly indicates the place of heat accumulation in the tooth profile. This is caused by the high pressure and friction in this area during operation [25].

Duzcukoglu H. [26], on the other hand, compared damage to the surface of the gearbox resulting from accumulated heat in the tooth body. The gears for testing were prepared using $\mathrm{CNC}$ cutting. The driving component was made of AISI 8620 steel and the driven gear of PA6. The researcher compared the distribution of heat generated in the polymer in two systems with a standard tooth profile and in a system with a gear with triple holes drilled in the body [26].

The test started with a pre-driven system to develop a smooth tooth surface. The load was then increased, with a constant speed. The test ended upon tooth damage or after exceeding the number of cycles of $4.2 \cdot 10^{5}$. In the system with additional radial holes, the heat distribution during operation of the polyamide 6 gear changed. It was shown that the drilled holes reduced the surface temperature of PA6 teeth and thus increased the resistance of the material to wear. Gears without cut-out cooling holes had a poorer heat transfer to the environment. In this case, the mechanical properties deteriorated due to material degradation. This phenomenon increased proportionally to the temperature increase resulting from rotational speed. The newly designed gears had a longer service life under most tested load conditions. It was only under drastic torques that the mechanical properties were observed to 
decrease due to the openings that weakened the material. The recorded temperatures of the systems revealed that, for standard gears the thermal epicentre was located in the central area of the tooth width. This confirms the researchers' assumption that heat would be transferred to the environment by drilling additional holes. Under high loads the materials in both systems were degraded and lost their mechanical properties after exceeding the glass transition temperature. The teeth were broken or melted, which caused bending of the profiles and other permanent damage. In summary, it was found that the newly designed gearboxes had a longer service life [26].

Team of scientists [22, 24, 27] chose seven glass fiber reinforced (GF) polyamides to replace the AISI 8620 metal wheel used in a worm gear in a truck's spare wheel. The research included: PA6, PA6 15\% GF, PA6 30\% GF, PA6 60\% GF, PA66, PA66 15\% GF, PA66 30\% GF. The researchers found that the addition of glass fiber, although it improved the stiffness and tensile strength of the composite, at the same time increased the unfavorable wear of gear teeth in comparison to pure polymer [20]. It turned out that glass fiber reinforced polymers had a higher dimensional stability due to a lower volume expansion coefficient of polyamide 6 [21]. The results obtained for dry and conditioned tested parts were compared. Conditioned PA66 demonstrated an almost $20 \%$ loss of tensile strength compared to dried material. The presence of moisture reduced the stiffness and modulus of elasticity to varying degrees depending on the type of polyamide. The difference in Young modulus between PA66 samples before and after conditioning was greater than in the case of PA6 (except for PA6 $15 \%$ GF and PA66 15\% GF). This was because of the hydrogen bonds which had formed with the water molecules of the respective polyamide functional groups. The best results in terms of stiffness, tensile strength and modulus of elasticity were obtained for PA6 60\% GF, PA6/66 30\% GF and PA6 30\% GF. The impact test carried out allowed to determine how the energy would be absorbed by the gears at a sudden load (e.g. driving a car on a bumpy road). PA6 60\% GF, PA6 and PA66 30\% GF showed the highest impact strength. The differences in impact strength due to the moisture content of the materials were greater for PA6. The resistance of the composites to abrasion, which causes mutual shifting of interlocking elements and loss of weight, was also compared. It was also determined that with an increase in the fiber content in the composite, the abrasion resistance of the gears increased regardless of the type of material conditioning. Two $30 \%$ and $60 \%$ glass fiber reinforced polyamides were selected for final testing. During the tests of a gear system made entirely of PA6 60\% GF, surface damage to the tooth occurred after 161 cycles. The second system, using PA6 30\% GF, was damaged after 623 cycles in the same areas of the gears [13].

The last set tested consisted of a PA6 60\% GF pinion shaft and a PA $630 \%$ GF gear. After 1200 cycles, the system was stopped, having worked without any failures. The success of this set was determined by the choice of
PA6 60\% GF as the pinion shaft material (high stiffness and tensile strength) and the gear wheel made of PA6 $30 \%$ GF (in which moisture absorption does not affect the abrasion of the component). Fiber reinforcement of polymer gearboxes results in lower wear and better shape retention depending on the temperature [13].

Another team of scientists [28] compared the properties of worm gears made of 25\% (Minlon 73GM40, DuPont Inc., Ulsan, Republic of Korea) and 50\% (Durethan AKV50H2.0, Lanxess) glass fiber reinforced PA66. The aim of the research was to replace the power steering control component in family sedans with the selected material. The material had to have dimensional accuracy, wear resistance, hardness, low noise and low vibration. Analysis of injection as well as stresses and deformations depending on the shape of the tooth was performed. It was found that the brittleness and strength of the material rise with an increase in glass fiber content. A structural analysis helped determine that a worm gear was more advantageous in terms of stress.

Duzcukoglu [29] tried to modify the strength of the gear made of PA66 by changes in the tooth profile. As previously described, high loads and speed increase the risk of failure due to heat build-up on the tooth surface. According to Hertz's assumptions, maximum surface pressure occurs at the point of contact of a pair of teeth. The aim of the study was to delay the occurrence of thermal damage by reducing the Hertzian surface by increasing the width of the tooth in a single contact.

The material used was 30\% glass fiber reinforced PA66 with increased resistance to thermal aging. In the first stage of testing, the gearbox speed was $200 \mathrm{rpm}$ and the load was $3 \mathrm{~N} / \mathrm{mm}$. The rotational speed and the load torque were increased successively. The depth of tooth wear for the different profiles was determined by dividing the height into the 16 sections. It was noted that near the base, wear was the greatest due to the opposite directions of the gears rolling and sliding. The depth of wear along the profile was relatively lower for modified profiles compared to standard ones. As the load increased, material losses increased especially in the root and top land areas.

As a result of the increased surface of a single profile in the modified gear, the accumulated heat in this area was reduced by the force/width ratio of the tooth for both loads. The damage to the modified teeth at constant speed varied according to the load. It was observed that an increase in the speed and load of the gear system translated into an increase in temperature at the inclination point the dividing line point. The researchers observed that the material between cracks in both gears was worn out as a result of melting of the tooth surface and, consequently, glass fiber being pulled out from the polymer matrix. The results of the research were used to develop structural assumptions for injection molds, which led to material savings through an increase in the width of teeth in the middle part. This helped achieve 
lower costs and longer working time of dimensionally modified gears [29].

Senthilvelan and Gnanamoorthy [27], analyzed noise generation during operation of wheels made of PA66 and composites with $20 \%$ of added glass or carbon fiber. The authors of the study observed a great impact of the fiber length, volume fraction and orientation, and of the degree of homogenization of fibers with the polymer matrix on the strength of the composite. The tested gears were made to match SS316 stainless steel wheels. The research showed that the composite gears produced more noise than those obtained from unfilled PA66. The tests were carried out at $1000 \mathrm{rpm}$ and within a torque range of 1.5 to $3 \mathrm{~N} \cdot \mathrm{m}$, which corresponds to a bending stress of 15 to $30 \mathrm{MPa}$. The tests were ended in case of failure or after 5 million cycles. For unreinforced PA66, a large number of surface cracks was observed in the middle of the tooth height at a bending stress of $15 \mathrm{MPa}$. The low thermal conductivity of the unfilled material caused local deformations when the teeth rolled in non-lubricated conditions. Cracks were observed at the base of teeth of all materials used at bending stress of $20 \mathrm{MPa}$. Optical microscopes and SEMs were used to establish that in the case of reinforced materials, glass and carbon fibers were oriented in a direction perpendicular to the applied force, which delayed cracking. If the direction of the fibers is parallel during operation, the fibers might be abraded due to their brittleness and penetration into the system. On the basis of observations of brittle fractures, the authors concluded that glass fibers showed much higher adhesion to PA66 matrix than that of carbon fiber composites. These findings were confirmed by the periodic measurements of tooth thickness. A comparison of the surface temperature during operation revealed a decrease in the case of reinforced composites. This was due to the greater thermal conductivity of the reinforced materials, which gave rise to an easier heat removal from the system. The wear of a tooth led to an increase in the gap between the cooperating parts and caused an increase in vibration and noise. It was determined without a doubt that the reinforcement of the polymer matrix resulted in higher mechanical strength, abrasion resistance and thermal conductivity [30].

\section{POLYOXYMETHYLENE AND POLYOXYMETHYLENE COMPOSITE GEARBOXES}

Polyoxymethylene (POM) is one of the most popular polyacetals used in the production of machine elements (e.g. gears) [15]. As is commonly known, it is a thermoplastic polymer with a high degree of crystallinity (about $80 \%$ ). The melting point of its crystalline state is about $175^{\circ} \mathrm{C}$ and the pour point is $190-200^{\circ} \mathrm{C}$ [31]. It is a material with excellent abrasion resistance as well as mechanical strength [32], high stiffness and hardness, which makes it an ideal and versatile construction material, also in case of atypical and complex shapes of machine components. It has very good dimensional stability [32], due to a low thermal expansion coefficient, good sliding properties and high impact strength even at low temperatures. It shows resistance to mineral oils, solvents and propellants, but is not resistant to acids and oxidizing agents. POM offers good creep resistance, outstanding resilience and very low water absorption. It is a good electrical insulator [33]. In addition, POM exhibits good resistance to abrasion and material fatigue. POM is processed by injection molding, extrusion and pressing [16, 34]. The processing temperature for $\mathrm{POM}$ varies between 210 and $230^{\circ} \mathrm{C}$, because above this temperature the compound breaks down into output monomers with gaseous formaldehyde. During processing, a large number of reactions takes place, and small changes in the molecular structure cause a significant alteration of POM properties. The properties of POM can be improved by strengthening the polymer matrix with short glass, carbon and basalt fibers $[16,34,35]$. The presence of strong fiber on the molding surface worsens the surface roughness but significantly increases the stiffness of the produced machine component.

In order to obtain POM composites with a low friction coefficient and high wear resistance, an effective addition of calcium salt of octaoxanoic acid, abbreviated as Ca-OCA, is used [36]. The role of the alkyl group of this compound is to reduce the coefficient of friction as its molecular structure is similar to that of wax, which is widely used as a mold lubricant. The addition of even a trace of this substance is quite effective in reducing the coefficient of friction as well as the rate of wear of the part. Such copolymers have a higher chemical resistance than unmodified POM.

Singh [12] and his team compared three different thermoplastic materials, i.e. acrylonitrile-butadiene-styrene (ABS), high density polyethylene (HDPE) and polyoxymethylene (POM) for use in gearboxes made of injection molded polymers. The amount of heat released and gearbox wear depending on the increase in temperature, torque and speed were examined. Finally, the condition of the teeth was analyzed at certain values of speed and torque in order to measure tooth loss, durability and the resulting damage. The test results showed that the ABS gearbox failed due to rapid abrasion of the tooth surfaces, while the cause of HDPE's failure was tooth cracking at the base. The POM gearbox was able to perform 2 million cycles without any failures and this material proved to be the most suitable for use in gear wheels [12].

Mao and his team [37] examined the temperature of a two-gear system and the distribution of heat generated during operation in the case of components with additional holes. The aim was to determine the effect of holes in the gear tooth on the reduction of heat generated and wear observed at high speeds and loads of the systems. In the case of polyacetals, it was found that wheels with drilled holes had a longer service life, due to 
the decrease in working temperature [37]. In subsequent tests, the researcher and his team focused their attention on the wear of an acetal gearbox, made by machining and by injection molding. A test platform was constructed to assess the impact of misalignment at the teeth contact point and to record the operation of teeth under constant load. The gear wheels were loaded with torque to a certain constant level despite continuous wear of the teeth. During the tests, the concentricity of the system, torque, speed, wear and time to failure of the components were checked. Photographs of the topography of the material showed that the cause of the failure was a temperature rise resulting from the friction of teeth at the contact points of the gears.

Similar tests for gears obtained by injection molding have been published by W. Li's team [38]. It was found that the tooth pressure angle increases proportionally with the wear of its profile. It was found that a change in the tooth geometry, i.e. the tooth top land and its base, affects the change of local stresses at the mesh point and reduces friction during work [38].

Based on the tests, a dependency was established to predict the temperature of the side surface of non-lubricated transmission components. It was found that the wear of the wheel teeth can be divided into three stages: the runin period, continuous operation and the final rapid wear period [3]. It was observed that a loss of about 33\% of the tooth thickness causes damage to the gears. The authors noted that teeth abrasion can be caused not only by high deformation during tests, but also by high loads leading to melting of the material and subsequent misalignment of the system. They also compared the incremental link between the load and the number of cycles made by the gearbox until failure. For this purpose, dynamic load changes, which produce system strength data much more quickly, were applied. The results of wear tests on acetyl wheels in time were determined as the amount of material removed per single cycle, at a constant speed of 1000 rpm and a torque of $7.5 \mathrm{~N} \cdot \mathrm{m}$ [11].

Weight loss of mass increased rapidly after approx. $12 \cdot 10^{6}$ work cycles. The subsequent test results were aimed at determining the critical torque. The results showed that below $9 \mathrm{~N} \cdot \mathrm{m}$, the gearbox wore out slowly and its operation lasted relatively long - for about $10^{7}$ cycles [11]. The wear rate of an acetyl tooth was determined, and was $5.14 \cdot 10^{-15}\left[\mathrm{~m}^{3} \cdot \mathrm{N}^{-1} \cdot \mathrm{m}^{-1}\right]$. This value can be compared to that of steel bearings, equal to $3 \cdot 10^{-15}\left[\mathrm{~m}^{3} \cdot \mathrm{N}^{-1} \cdot \mathrm{m}^{-1}\right]$ [11]. The torque and speed, which was close to the melting point of acetal $\left(165^{\circ} \mathrm{C}\right)$, were also determined. When the critical load of the system was exceeded, the wheels failed due to thermal wear. In summary, the fatigue tests described in the paper showed that regardless of the production process, gear wear indicators are comparable. A sharp increase in wear occurred when the torque transmitted reached a critical value determined by the geometry of the gearbox. This was due to the fact that the surface temperature of the material approached its melting point [3].
For subsequent tests, the authors of study [8] designed a testing platform capable of continuous measurement of gear surface wear under constant load. Parameters such as torque, speed, material wear in relation to changes in tooth width at the inclination point and number of cycles to failure were recorded. The tests were carried out for gearboxes made by injection molding from Delrin 100 (POM). The system consisted of two polymeric gears with a $2 \mathrm{~mm}$ modulus and featuring 20 teeth driven at a pressure angle of 20 degrees for both drive wheels under unlubricated conditions. The tests were performed at a wheel speed of $1000 \mathrm{rpm}$ with a load between 7 and 16.1 N.m. The gearbox operating period was divided into three phases: a run-in period, linear operation and the final rapid wear period during which material wear rises quickly. It was found that the wear of the gearbox at a constant torque in the range 8.5-9.0 N.m increases sharply at the point of reaching the critical load, depending on the geometry and speed of the system. This is due to an increase in the operating temperature of the gearbox reaching its melting point at the critical load point. A failure would occur at a wear of about $40 \%$ of the teeth thickness due to a broken or softened tooth. For torques above $9.5 \mathrm{~N} \cdot \mathrm{m}$, there was rapid wear after the start of the tests and the size of the torn off particles was larger. An infrared camera was used to determine that the temperature in which the failure occurs is close to the melting point of polyacetals, i.e. about $175^{\circ} \mathrm{C}$ [8].

Bahadur et al. found in their work that the addition of only a few per cent of inorganic fillers improved the tribological properties of polymers. The use of small amounts of additives (above 10\%) in the polymer matrix such as: polytetrafluoroethylene (PTFE), molybdenum disulfide $\mathrm{MoS}_{2}$ or graphite in the design of gears reduced friction [23, 39, 40].

Kurokawa and Uchiyama [41], in their research on wear of gears made of polyoxymethylene-POM, proved that the addition of small amounts of powdered silicon carbide $\mathrm{SiC}$ of $0.28 \mathrm{~mm}$ grain size improved wear resistance while maintaining the same friction coefficient as for unfilled POM. The modification resulted in an increased Izod's impact, with no effect on tensile and flexural strength [41]. In yet another study, Kurokawa and Uchiyama compared tribological properties of POM containing traces of silicon carbide $\mathrm{SiC}$, calcium salt of montanic acid $\left[\mathrm{CH}_{3}\left(\mathrm{CH}_{2}\right)_{26} \mathrm{COOH}\right]$, abbreviated as Ca-OCA, and polytetrafluoroethylene (PTFE) [36]. The researchers made a series of blends containing small amounts of $\mathrm{SiC}$ and $\mathrm{Ca}-\mathrm{OCA}$ modifiers by pumping additives with POM, and then prepared standardized samples for testing. The impact of spherulite size was evaluated using a measuring microscope. Using a strain gauge sensor and a non-contact displacement transducer, measurements were taken to evaluate tribological properties and performance of the tools: the coefficient of friction, wear and load of elements, generated noise and tooth temperature. The test parameters included: contact pressure of $0.7 \mathrm{MPa}$ 
and rotation speed of $0.5 \mathrm{~m} / \mathrm{s}$. Measurements were taken at room temperature without additional lubrication of the system. It was found that the coefficient of friction was significantly reduced due to the addition of $\mathrm{Ca}-\mathrm{OCA}$ in the POM/SiC composite. The increase in crystallization led to a decrease in gear wear. Relatively comparable properties were obtained for POM/SiC (0.1 wt \%)/Ca-OCA (0.1 wt \%) and POM/PTFE (24 wt \%) composites [36].

\section{SUMMARY}

The rapid development of science and technology has enabled many new materials to be developed over the last few decades to meet the ever increasing demands of designers and technologists. New materials introduced into the industry had higher mechanical properties compared to the used engineering and functional materials. Particularly dynamic progress is visible in the case of polymeric materials currently applied in machine and plant construction - they have replaced metallic materials. Initially, polymeric materials were introduced to industry as a material for less loaded machine components. They are already successfully used for responsible machine components and subcomponents, including protective coatings operating in difficult conditions. The demand for modern polymers results from their many advantages, including low density, high chemical resistance, ease of molding and dyeing of products of the assumed shape and size, good durability and low manufacturing costs. They can also work at elevated temperatures for a long time, hence their use in the manufacture of machine components, including gears and gear shafts, clutch components and housing, rotors, slide bearings and worm gears.

Development of a new technology for production of parts from polymer materials with significantly improved mechanical and visual properties Nr POIR.01.01.01-00-0760/18

\section{REFERENCES}

[1] Thirugnanam A., Sathish J., Rakesh L.: Middle-East Journal of Scientific Research 2014, 20 (3), 362. http://dx.doi.org/10.5829/idosi.mejsr.2014.20.03.11340

[2] Mao K., Li W., Hooke C. et al.: Wear 2009, 267, 639. http://dx.doi.org/10.1016/j.wear.2008.10.005

[3] Mao K., Langlois P., Hu Z. et al.: Wear 2015, 332-333, 822. https://doi.org/10.1016/j.wear.2015.01.084

[4] Oleksy M.: „Technologia Rapid Prototyping hybrydowych nanokompozytów polimerowych stosowanych na koła zębate", Wydawnictwo Politechniki Rzeszowskiej, Rzeszów 2014.

[5] Mehat N.M., Kamaruddin S., Othman A.R.: Advanced Materials Research 2012, 591-593, 2135.

http://dx.doi.org/10.4028/www.scientific.net/ AMR.591-593.2135
[6] Snyder L.: Gear Technology 2010, 27, 26.

[7] Bravo A., Koffi D., Toubal L. et al.: Engineering Failure Analysis 2015, 58, 113

http://dx.doi.org/10.1016/j.engfailanal.2015.08.040

[8] Mao K., Li W., Hooke C.J., Walton D.: Tribology International 2010, 43, 433.

https://doi.org/10.1016/j.triboint.2009.07.006

[9] Koffi D.: "Étude du comportement thermique des engrenages cylindriques droits en plastique", École Polytechnique 1988.

[10] Mao K.: Wear 2007, 262, 432. https://doi.org/10.1016/j.wear.2006.06.005

[11] Friedrich K.: "Friction and Wear of Polymer Composites", "Composite Materials Series 1", Elsevier Science Publications B.V., Amsterdam 1986.

[12] Singh P.K., Siddhartha, Singh A.K.: Tribology International 2018, 118, 264. https://doi.org/10.1016/j.triboint.2017.10.007

[13] Gasparin A., Corso L., Tentardini E. et al.: Materials Research 2012, 15 (3), 483. http://dx.doi.org/10.1590/S1516-14392012005000056

[14] Hałasa E., Heneczkowski M.: „Wprowadzenie do inżynierii termoodpornych materiałów polimerowych", Wydawnictwo Politechniki Rzeszowskiej, Rzeszów 2007.

[15] Bociąga E., Jaruga T., Sikora R.: Polimery 2009, 54, 522. http://dx.doi.org/10.14314/polimery.2009.522

[16] Sikora R.: „Obróbka tworzyw wielkocząsteczkowych", Wydawnictwo Edukacyjne, Warszawa 1996.

[17] Sikora R.: „Przetwórstwo tworzyw polimerowych. Podstawy logiczne, formalne i terminologiczne", Wydawnictwo Politechniki Lubelskiej, Lublin 2006.

[18] Alauddin M., Choudhury I.A., El Baradie M.A. et al.: Journal of Materials Processing Technology 1995, 54, 40. https://doi.org/10.1016/0924-0136(95)01917-0

[19] Kochan D., Kai C.C., Zhaohui D.: Computers in Industry 1999, 39, 3.

[20] Wright N.A., Kukureka S.N.: Wear 2001, 251, 1567. https://doi.org/10.1016/S0043-1648(01)00793-1

[21] La Carrubba V., Butters M., Zoetelief W.: Polymer Bulletin 2008, 59, 813. http://dx.doi.org/10.1007/s00289-007-0819-0

[22] Kurokawa M., Uchiyama Y., Nagai S.: Tribology International 1999, 32, 491. http://dx.doi.org/10.1016/S0301-679X(99)00078-X

[23] Bahadur S., Polineni V.: Wear 1996, 200, 95. https://doi.org/10.1016/S0043-1648(96)07327-9

[24] Kurokawa M., Uchiyama Y., Nagai S.: Tribology International 2000, 33, 715. http://dx.doi.org/10.1016/S0301-679X(00)00111-0

[25] Terashima K., Tsukamoto N., Nishida N. et al.: Bulletin of JSME 1986, 29, 1598. https://doi.org/10.1299/jsme1958.29.1598

[26] Duzcukoglu H.: Tribology International 2009, 42, 1146. https://doi.org/10.1016/j.triboint.2009.03.009

[27] Senthilvelan S., Gnanamoorthy R.: Applied Composite Materials 2006, 13, 237. 
http://dx.doi.org/10.1007/s10443-006-9016-9

[28] Kim G.H., Lee J.W., Seo T.: Materials 2013, 6 (5), 1873. http://dx.doi.org/10.3390/ma6051873

[29] Duzcukoglu H.: Materials and Design 2009, 30, 1060. http://dx.doi.org/10.1016/j.matdes.2008.06.037

[30] Senthilvelan S., Gnanamoorthy R.: Polymer Testing 2006, 25, 56.

https://doi.org/10.1016/j.polymertesting.2005.09.005

[31] Liu X., DeVor R.E., Kapoor S.G. et al.: Journal of Manufacturing Science and Engineering 2004, 126, 666. https://doi.org/10.1115/1.1813469

[32] Oczoś K., Liubimov V.: „Struktura geometryczna powierzchni", Oficyna Wydawnicza Politechniki Rzeszowskiej, Rzeszów 2003.

[33] Park S.C.: Computer-Aided Design 2003, 35, 27. https://doi.org/10.1016/S0010-4485(01)00173-7

[34] Schmitz T., Davies M., Dutterer B. et al.: International Journal of Machine Tools \& Manufacture 2001, 41, 1209.
[35] Shin B.S., Yang D.Y., Choi D.S. et al.: Journal of Materials Processing Technology 2002, 130-131, 363.

[36] Kurokawa M., Uchiyama Y., Nagai S.: Journal of Tribology 2000, 122, 809. http://dx.doi.org/10.1115/1.1288773

[37] Mao K: “Wear characteristic of non-metallic gears", School of Manufacturing and Mechanical Engineering, Birmingham 1993.

[38] Li W., Wood A., Weidig R. et al.: Wear 2011, 271, 2176. https://doi.org/10.1016/j.wear.2010.11.019

[39] Yu L., Bahadur S.: Wear 1998, 214, 245. https://doi.org/10.1016/S0043-1648(97)00234-2

[40] Bahadur S., Gong D.: Wear 1993, 160, 131. https://doi.org/10.1016/0043-1648(93)90414-H

[41] Kurokawa M., Uchiyama Y.: Tribologist 1999, 44, 544. Received 3 III 2020.

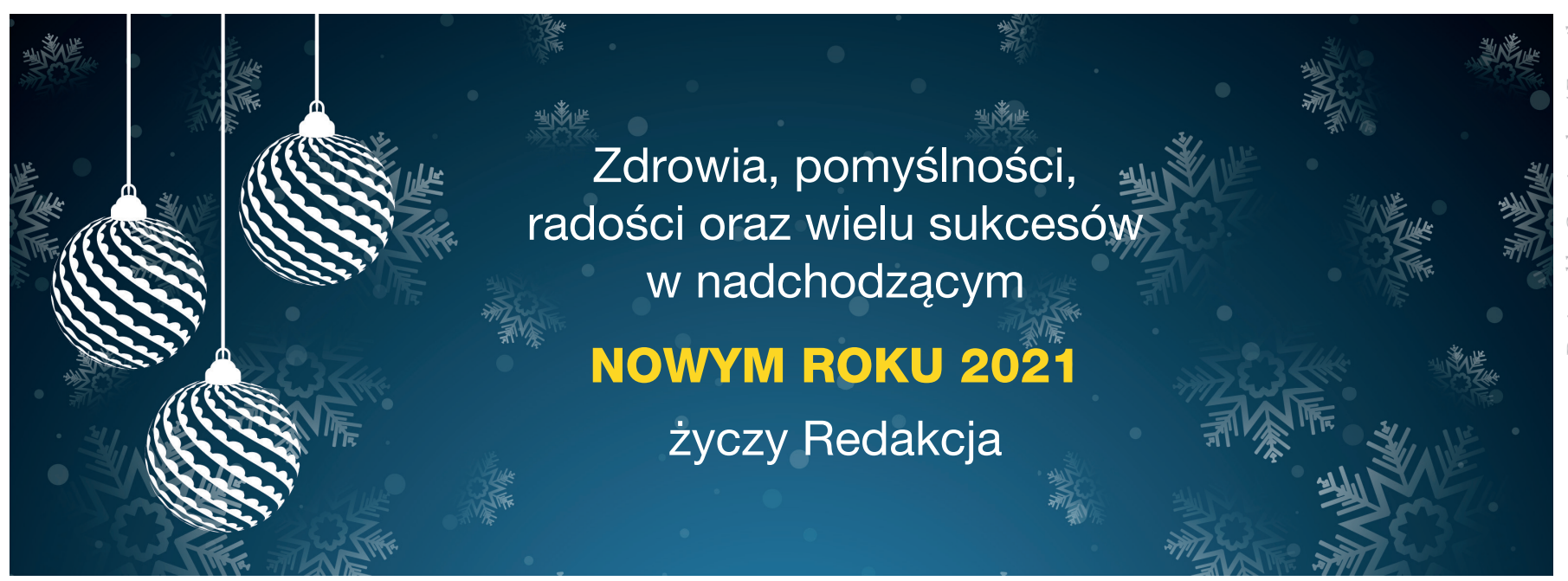

